\title{
Belgeo
}

Revue belge de géographie

1 | 2008

Aspects of the history of the Belgian geography and cartography

\section{Bosatlas der Nederlanden}

$53^{\text {ste }}$ editie, Wolters-Noordhoff, Groningen, $560 \mathrm{p}$.

\section{Trudo Dejonghe}

\section{OpenEdition}

\section{Journals}

Édition électronique

URL : http://journals.openedition.org/belgeo/10224

DOI : 10.4000/belgeo.10224

ISSN : 2294-9135

Éditeur :

National Committee of Geography of Belgium, Société Royale Belge de Géographie

Édition imprimée

Date de publication : 31 mars 2008

Pagination : 141-142

ISSN : $1377-2368$

Référence électronique

Trudo Dejonghe, « Bosatlas der Nederlanden », Belgeo [Online], 1 | 2008, Online op 19 octobre 2013, geraadpleegd op 22 septembre 2020. URL : http://journals.openedition.org/belgeo/10224 ; DOI : https://doi.org/10.4000/belgeo.10224

Ce document a été généré automatiquement le 22 septembre 2020.

Belgeo est mis à disposition selon les termes de la licence Creative Commons Attribution 4.0 International. 


\title{
Bosatlas der Nederlanden
}

\author{
$53^{\text {ste }}$ editie, Wolters-Noordhoff, Groningen, $560 \mathrm{p}$.
}

\section{Trudo Dejonghe}

\section{RÉFÉRENCE}

$53^{\text {ste }}$ editie, Wolters-Noordhoff, Groningen, 2007, $560 \mathrm{p}$.

1 Aan de $53^{\text {ste }}$ editie van de "Bosatlas der Nederlanden" ging ruim twee jaar werk van redacteurs en cartografen vooraf. Het resultaat is meer dan vijf kilogram wegende uit 560 pagina's en meer dan 2400 kaarten bestaande editie die meer onderwerpen covert dan de traditionele atlassen. Wolters Noordhoff Atlasproducties noemde de atlas dan ook: "Een spectaculaire ontdekkingsreis door eigen land en een uiting van nationale trots". In de weken na de verschijning van de atlas bleek dat het Nederlandse publiek het met de uitgever eens was. De eerste druk van de atlas was binnen een week uitverkocht en versloeg zelfs "Harry Potter en de relieken van de dood" in de strijd om de eerste plaats op de lijst van meest verkochte boeken in Nederland. In de weken na de verschijning leidden kaartbeelden uit de atlas zelf tot publieke discussies. Inwoners van Westland (de glastuinbouwstreek onder den Haag) waren het er niet mee eens dat hun regio als landschappelijk onaantrekkelijk gekarteerd was. Carnavalsverenigingen uit de zuidelijke provincie Noord Brabant waren verbolgen over het feit dat niet alle carnavalsdorpen vermeld waren en de aanwezigheid van De "Voetbalkaart van Nederland" zorgde dat zelfs voor een bijdrage in het NRC Handelsblad. De gecoverde thema's variëren van "autodiefstallen tot zeeweringen" en overdonderen de gebruikers met allerlei feitjes en weetjes over Nederland.

Belgen zullen in de atlas misschien tevergeefs zoeken naar aanknopingspunten met hun land. Met uitzondering van het eerste op de "Geschiedkundige Atlas van Nederland" gebaseerde historische deel is de atlas bijna in zijn geheel gewijd aan Nederland en de Nederlanders en is bijna iedere invloed van buiten de landsgrenzen geëlimineerd.Cartograaf Barend Kobben merkte bijvoorbeeld op dat de inwoners van Zeeuws Vlaanderen ten onrechte op grote afstand van een stedelijk centrum 
gekarteerd worden, de nabijheid van Antwerpen zou een andere kleur op deze choropleetkaart rechtvaardigen. Toch zijn er ook voor Belgische gebruikers interessante kaarten met mogelijk een praktisch gebruiksnut: in de overzichtskaart van wederzijdse migraties (pagina 331) tussen Nederland en België lijkt het erop dat de afstandsfrictie de migratie van Nederlanders bepaalt, terwijl Belgen ook naar verder gelegen (universiteit)steden in Nederland migreren. De kaart over het aantal drugsmisdrijven in Nederland is een relevante voor het dispuut tussen de Nederlandse gemeente Maastricht en haar Belgische buurgemeenten over het al dan niet vestigen van een drive in coffeeshop. Het blijkt dat het aantal drugs gerelateerde misdrijven in Maastricht twee maal zo hoog ligt als het Nederlandse gemiddelde en binnen Nederland alleen zijn gelijke vindt in Amsterdam.

3 Voor Belgische (dag)toeristen biedt de atlas mogelijk inspiratie bij het kiezen van hun bestemming. De landschapsfoto's van Karel Tomei kunnen inspiratie opleveren voor een bezoek aan de noorderburen en de overzichtskaart van Unesco-monumenten en musea maakt het raadplegen van toeristische informatie een stuk gemakkelijker. En voor de kartografische beroepsgroep ? Zij zullen wellicht inspiratie op kunnen doen in de heldere "Bos"karteringsstijl van de kaartenmakers van Wolters Noordhoff, waarin zoals altijd de kleurkeuze en de kunst van het weglaten geleid hebben tot zeer goed leesbare kaartbeelden.

Deze atlas stelt ons Belgen bovendien eveneens voor de vraag of dergelijk werk voor België ook geen verkoopsucces zou worden. De mooi verzorgde atlas zou net zoals de door het Gemeentekrediet in 1992 uitgegeven "Geografie van België" een standaardwerk worden en door vele mensen als een mooi boek of relatiegeschenk kunnen beschouwd worden of past "Een spectaculaire ontdekkingsreis door eigen land en een uiting van nationale trots" niet meer in onze denkbeeld? 